\title{
Tracing Environmental Sustainability Discourses: An Australia-Asia Seafood Case Study
}

\author{
Coco Cullen-knox ${ }^{1,2 *}$, Aysha Fleming ${ }^{1,3}$, Libby Lester ${ }^{1,2,4}$ and Emily Ogier1,5 \\ ${ }^{1}$ Centre for Marine Socioecology, University of Tasmania, Hobart, TAS, Australia, ${ }^{2}$ The Media School, University of \\ Tasmania, Hobart, TAS, Australia, ${ }^{3}$ CSIRO Land and Water, Hobart, TAS, Australia, ${ }^{4}$ Institute for Social Change, University of \\ Tasmania, Hobart, TAS, Australia, ${ }^{5}$ Institute for Marine and Antarctic Studies, University of Tasmania, Hobart, TAS, Australia
}

\section{OPEN ACCESS}

Edited by:

Liping Liu,

Shanghai Ocean University, China

Reviewed by:

Catherine Sarah Longo, Marine Stewardship Council (MSC),

United Kingdom

Richard Le Heron,

The University of Auckland,

New Zealand

*Correspondence:

Coco Cullen-knox

cullenc@utas.edu.au

Specialty section

This article was submitted to

Marine Fisheries, Aquaculture and Living Resources,

a section of the journal

Frontiers in Marine Science

Received: 29 June 2019

Accepted: 05 March 2020

Published: 24 March 2020

Citation:

Cullen-knox C, Fleming A, Lester L and Ogier E (2020) Tracing

Environmental Sustainability

Discourses: An Australia-Asia

Seafood Case Study.

Front. Mar. Sci. 7:176.

doi: 10.3389/fmars.2020.00176
The seafood market is highly globalised with a growing demand for seafood and fish products worldwide. The capacity of wild fisheries is limited and therefore aquaculture is fast becoming the most stable source of seafood to meet increasing demand. Subsequently, the perceived environmental risk of fin-fish aquaculture has been the focus of substantial environmental campaigning, media and public scrutiny around the world. This paper places localised tensions regarding the environmental impacts of salmon aquaculture within transnational environmental sustainability debates concerning seafood production and vice-versa, with a focus on the Australia-Asia region. The results contribute to understanding the interpretation and communication of environmental sustainability of seafood through international supply chains and to audiences at different spatial scales. The paper draws particularly on the case of salmon aquaculture in Tasmania, Australia's southern island state. It highlights mechanisms, such as certification, for which information flows transnationally regarding the environmental sustainability of seafood production, the resultant transnational and local public sphere and the implications for local discourse, market access, governance and certification of seafood production.

Keywords: environment, sustainability, Australia, Asia, seafood, aquaculture, transnational

\section{INTRODUCTION}

Seafood products are some of the most highly traded food commodities globally (FAO, 2016). Demand for seafood, driven by a growing population, particularly the Asian middle class, requires the increased use of natural resources globally (Cao et al., 2017). Accompanying this increased pressure on natural resources to sustain the human population is the rise in awareness of sustainable development. Sustainable development encompasses the concept that human life is sustained within the limits of earth's carrying capacity so that future generations are unimpacted (IUCN, 1980). The environmental sustainability construct is both widely used and widely disputed (Seghezzo, 2009). Environmental sustainability can be approached from either the perspective of how best to protect environmental attributes or how to most optimally use an environmental resource. Also variously interpreted is how these perspectives fit in with the construct of sustainable development.

Given the transnational reality of seafood markets and communication mechanisms, who gets to define environmentally sustainable seafood production and the mechanisms by which they define it is expected to shift with scale. Global risk discourse regarding the environmental sustainability of 
seafood production and harvest are increasingly encompassing the notions of the "locally affected" and "distant aware" (Lester, 2014). For local communities, environmental impact, or the risk of impact, is a lived experience. However, distant consumers, or those simply with an interest, can be alerted to potential environmental risks in another location via mechanisms such as media, campaigning or food labeling. These distant communities of interest can still participate in the issue through strategies such as social media or changing their purchasing practices. Within the context of the "transnational public sphere" (Fraser, 2007: 15), how perceptions of local and global environmental risks of seafood flow transnationally is becoming increasingly relevant.

This paper builds on scholarship by Lester (2016) who investigates the production and flow of environmental messages in a transnational context. Lester's investigation reveals environmental campaign organizations engaging transnationally in an attempt to protect the Great Barrier Reef from anthropological impact. The sensationalist media campaigns target international corporations investing in Australia, distant consumers, and international environmental governance organizations highlighting the environmental risks and lack of "social licence" (see also Cullen-Knox et al., 2017). These campaigns also allocate responsibility to "global citizens" (Lester, 2016) to remind global organizations and the Australian government of their accountability to protect important environments.

Both public and private governance structures influence how sustainable seafood is defined at any given time and space. In his examination of the interpretation of sustainability standards in international fisheries policy, Rice (2014) observes how the malleable nature is accentuated over time. To define and standardize global benchmarks for environmentally sustainable seafood production, market-based mechanisms such as thirdparty certification schemes have been developed. A third-party certification label is one of the few ways for customers to determine what is considered to be sustainable seafood. However, despite efforts to standardize the definition for sustainable seafood, "sustainability" has been so overused as a marketing tool that some argue it has become meaningless and lost its value and impact (McEwan and Bek, 2009). There are also concerns that external sustainability assessments could undermine government authority (Crona et al., 2016).

International trade can also emphasize the disconnect between impact on local environments and demands from distant markets (Steneck et al., 2011). What is considered important changes across local and global environments, debates, and markets. For example, seafood traders in China view green labeling and concerns of environmental sustainability as less important compared to other factors such as food safety (Fabinyi et al., 2017). The risk of continued environmental impact can be considerable if this disconnect is not addressed through effective governing mechanisms. Therefore, understanding how the interpretation of environmental sustainability is modified transnationally is increasingly important to local and global governance of internationally traded seafood.

The recognition of regionally specific perceptions of "best practice" and the resistance against the global monopoly some international certification schemes have over assessment of sustainable practices and subsequent product labeling is visible in the emergence of territorial certification schemes (Foley and Havice, 2016). Foley and Havice (2016) note that for these schemes to be successful they must integrate state regulation and interests of seafood producers with international markets and governance norms and must operate credibly within transnational commodity networks. Interactions between the network of actors and their governance frameworks also contributes to the perception of environmentally sustainable seafood. When discussing transnational activism, the globalization of markets is commonly regarded as the trigger, however this fails to address the "when," "why" and "how" by different actors and their networks conduct transnational activism (Tarrow, 2005). Tarrow describes transnationalism as a set of international networks, creating society-like structures, that allow individuals to move effortlessly between scales and spheres of influence. Adding to this, Beck's (1996) "global risk society" and "cosmopolitism" encompass world-wide communications and global environmental risks, whereby political borders are transcended boundaries. This risk "can be dramatized or minimized, transformed or simply denied according to the norms that decide what is known and what is not." (Beck, 2011: 1349). This is exemplified by Lester (2014) describing where an Australian Environmental Non-Government Organisation (ENGO) launched a decade-long campaign persuading Japanese corporations that Tasmanian forestry companies and products were unsustainable. Simultaneously, direct action activism was occurring at the site of forestry practices. However, the practices of Tasmanian forestry companies only gained noticeable attention when the obtaining of certification became necessary to secure international markets and contracts for forestry production. Here the risk was avoided until certification made the issue inescapable.

The environmental sustainability of seafood is prevalent in transnational market based governance discourses involving governments, seafood harvesters and producers, ENGOs, media actors, and consumers (Miller, 2014; Kate and Alice, 2018). However, there are limited theoretical literature and empirical case study examples to understand how environmental concerns are conveyed transnationally in relation to the role of media and environmental campaigning.

To explore how environmental concerns regarding seafood production are carried transnationally in the context of local production, international trade and global communications, this paper draws on one of Australia's topical environmental conflicts concerning seafood production: Fin-fish aquaculture in Tasmania. Marine coastal waters in Tasmania, Australia's southern island state, are used to farm Atlantic salmon for domestic consumption and export to Asian markets. However, the industry is facing considerable opposition from local community groups, local and national ENGOs and journalists. While local opposition remains, both domestic and international demand for Tasmanian Atlantic Salmon continues. Free trade agreements between Australia and Asian countries including China, Japan and Korea are making these export markets more accessible and are likely to increase demand for farmed Atlantic salmon, and thereby 
potentially increase the pressure on ecosystem services at sites of production.

The aim of this paper is to gain an understanding of how the potential or perceived environmental risks of seafood production (particularly salmon aquaculture) are understood, articulated, negotiated and potentially resolved across transnational media and communication networks, particularly in the Australia-Asia region. The growing Asian middle class is a significant influencer in food production and resource use globally. As we enter what an Australian Government 2014 white paper refers to as the "Asian Century," Asia is, and is set to continue to be, an important export market for Australia, with trade agreements being signed (Tasmanian Government, 2013). To identify how the construct of environmental sustainability of seafood flows transnationally the analysis identifies how environmental sustainability is defined and negotiated, who is involved and what mechanisms are used. To do this we ask:

(1) What are the perceptions of environmentally sustainable seafood production within an international community and which actors portray these perceptions?

(2) How do these perceptions influence local debates of environmentally sustainable production of seafood?

(3) How do local issues influence international discourse regarding the environmental sustainability seafood?

\section{Trade in the Australia-Asia Region; The Importance of Seafood and Salmon}

The Chinese seafood market (both production and consumption) is the largest in the world. Chinese consumption patterns are likely to have the strongest influence on global fish markets into the future with the region expected to account for $38 \%$ of the global consumption of seafood by 2030 (World Bank, 2014). These consumption patterns are highly relevant to global environmental outcomes. The scale of this consumption and the trend toward luxury species has been directly linked to overfishing and stock declines in some fisheries (Fabinyi et al., 2012; Cao et al., 2017). Rising demand for luxury seafood in China has initiated a "global blue gold rush" (Caplog Group and EDF Maxico, 2014). For example, in 2014, accessing the growing Chinese middle-class consumer became easier and cheaper with the launch of "Gfresh," an online marketplace facilitating the import of seafood to China, directly linking business and consumer. In the company's first 2 years of operation it is reported to have "processed more than \$200 million worth of wholesale live seafood orders" (Kolodny, 2017). The platform notes origin, species, and quality of their catch.

In 2015 Australia signed free trade agreements with Japan and China. Australia's trade relations with its Asian neighbors is a prominent agenda for governments and industries. At the 2016 G20 meeting the then Australian Prime Minister, Malcom Turnbull, with reference to trade between China and Australia, is reported as stating: "It would be a mistake of historic proportions for the G20 to stand by while scare campaigns not based on facts or evidence foster protectionism, or indeed isolationism," (ABC News, 2016). While this statement was made in reference to Australia blocking agricultural and electricity sales to China, this quote represented the trade atmosphere between China and
Australia and captures the Australian Governments sentiment regarding strengthening trade relations with China. In other words, G20 leaders should ignore economic scaremongering and be aware of the risks of opposition campaigning against efforts to strengthen trade relations, particularly with Asia.

The transnational flow of investment, resources and information is expected to increase and congregate in the Asian region. Lester's (2014) research into Australia's White Paper on the trade of goods and services in the Australia-Asia region, Australia in the Asian Century (Commonwealth of Australia, 2012), suggests that:

\begin{abstract}
if media and communications, community organizations and individuals (among others) have crucial roles to play in developing Australia's "two-way" links with Asia, these may only rarely present a "public diplomacy" stance that promoted the Australian government or business community's immediate interests. Instead, they will increasingly produce multi-directional and multi-layered flows of political communication and action in which distant supports join with those affected to resist development, end resource procurement and undermine growth strategies. How Australian government and industry choose to respond to and manage the economic and political impact of these protests and the still poorly understood transnational communities of environmental concern that result will be a crucial test of Australian claims to democratic and market leaderships among its regional neighbors in the Asian Century.
\end{abstract}

The subsequent 2013 white paper “Tasmania's place in the Asian Century" stipulated the opportunity for luxury export items as the Asian middle class is predicted to grow in value to three billion Australian dollars by 2030 and have the largest population of high-income earners in the world within the next 20-30 years. From 2013 to 2017 Australian export increased by $40 \%$ from $\$ 1$ billion to $\$ 1.4$ billion with exports to China forming most of this growth (Fabinyi, 2007). This paper identifies "enabling the expansion of salmon aquaculture in Macquarie Harbor," a large inlet on the west coast of Tasmania and the first area to farm salmon in Australia, as one of the key activities to build export strengths and sustainable development (Tasmanian Government, 2013: 43). However, this growth agenda is challenged when the Institute for Marine and Antarctic Studies (IMAS) is reported to have found salmon farming to be responsible for "environmental collapse" in Macquarie Harbor (Woodruff, 2017), highlighting the conflict between the growth and impact discourses. This tension is not expected to diminish with seafood now being the fourth largest export for Tasmania (Tasmanian Government, 2017), with international trade reported to have increased by $27 \%$ in 2015 , including a doubling of sales to China.

Australia only made up $0.3 \%$ of China's Atlantic salmon imports in 2017, with $0.53 \%$ from 2008 to 2018. Meanwhile, China made up $65 \%$ of Australia's total sales in 2017, an unusually high export year with 32\% increase from 2008 to 2018 (FRDC, 2018). Additionally, there is a growing discourse regarding Asian investment in Tasmanian salmon companies, the strengthening vertical monopolies that are forming and possible implications for future food security (Thompson et al., 2011, MacDonald, 2018, O'Conner, 2018). In emphasizing the significance of the Chinese market for the 
Australian economy and the relative insignificance of Australian product for China, these figures make clear the vulnerabilities of trade for Australia.

The link between China's consumption patterns and impact on global fish stocks, combined with Asia's contribution to Australian trade, further highlights the importance of investigating transnational flows of environmental concern (Fabinyi et al., 2017). With increased exports to China and Chinese investment in the state, Tasmania provides a unique and critical opportunity to explore what Lester (2014) describes as "multi-directional and multi layered" links with Asia and "poorly understood transnational communities of environmental concern" and the responses they elicit.

\section{Local Conflicts in Tasmania Concerning Salmon Aquaculture}

Salmon aquaculture in Tasmania has been a controversial industry since its inception in the early 1990s and acts as a local case study in this research. Three companies farm salmon in Tasmania: Tassal, Huon Aquaculture, and Petuna. Tassal is the largest of the three and Petuna the smallest. The act of farming salmon in public marine waters has been contested between those who hold environmentally centered ethics and those who support industrial growth in otherwise struggling regional communities.

Since 2012 the industry has undergone expansion, and with the support of the Tasmanian state government, announced production would double by 2030 (Tasmanian Government, 2013). The proposed expansion into new unfarmed areas in 2016 was preceded by a decline in environmental health of already farmed areas and a spate of regulatory attempts to manage these impacts. This sparked public debate regarding the adequacy of the governance mechanisms to manage the environmental impacts of the salmon industry. Subsequently, two critical discourse moments (Carvalho, 2005) occurred. In 2015 a Government led senate inquiry was held into the "Regulation of fin-fish aquaculture in Tasmania" where 103 public submissions were received followed by a 2 -day hearing. In 2016, local opposition groups were formed, environmental campaigns became prevalent and increased media attention took what was historically a locally contained conflict to audiences Australia wide with Four Corners, Australia's premier investigative journalism television program, airing an episode titled "Big Fish." This media attention has focused on how the environmental risk of the industries' expansion has been managed. The complex social networks that formed around these critical discourse moments are explored in previous work (Cullen-Knox et al., 2019).

One of the main ways for producers to inform purchasers and consumers that their practices are environmentally sustainable is through third-party certification (Hatanaka et al., 2005). In the case of the Tasmanian salmon industry, third-party certification, in addition to government regulation, has played a key role in the environmental governance of the industry. The Aquaculture Stewardship Council (ASC) scheme is the most visible in this case, with Tassal the first salmon company in the world to achieve ASC certification across all its operations (Tassal, 2018). Compared to local government regulations, the ASC scheme and standards are global in outlook. It brings, or is claimed to bring, sustainability standards based on scientific advice and management practices as applied in a range of countries to the localized site of production. Other Tasmanian salmon aquaculture companies hold third-party certification by other providers. However, the partnership between Tassal and ASC has been the most visible and contentious in the Tasmanian public discourse (Cullen-Knox et al., 2019).

Regardless of being ordered by the Environmental Protection Authority (EPA) to destock leases and receiving non-compliance notices, Tassal was perceived to retain ASC certification. However, Tassal opted to exclude these non-compliant leases in the ASC audit and therefore forfeited ASC certification for these leases. The ambiguity regarding this process and the uncertainty this created is present in the auditor's report (see SCS Global Services, 2017). In response, Environment Tasmania, a local ENGO, made claims that the ASC audit process, along with WWF partnership, was faulty and corrupt. Environment Tasmania initiated a petition "demanding that all certifications for Macquarie Harbor be suspended and a full and transparent review of just how Tassal has retained ASC certification while breaching key ASC standards for more than 18 months" (Environment Tasmania, 2016). Additionally, Environment Tasmania, developed a "Tasmanian Salmon Consumer Guide" to rank Tasmanian salmon companies based on a traffic light system. Criteria included salmon mortality rates, stocking density and escapees, bird and seal interactions, antibiotic use, genetic modification, dissolved oxygen levels, site water temperature and depth, capacity to flush waste, impact on protected species and areas and wild fish use in feed (Environment Tasmania, 2019). Simultaneously, Environment Tasmania commenced a campaign against transnational ENGO WWF for partnering with Tassal (see Cullen-Knox et al., 2019).

The difficulty of including local concerns in global governance schemes was highlighted during a public engagement meeting held by accredited third party auditors (Conformity Assessment Body at SCS Global Services) evaluating the application of the ASC standard in Hobart in 2017 regarding fin fish farming in Macquarie Harbor. This public engagement formed part of the ASC biannual audits for certified salmon farming sites. At the meeting concerns were raised in relation to the environmental impacts of salmon farming, primarily by ENGOs. For example Environment Tasmania, a Tasmanian ENGO, is reported as stating "Tassal did not deserve ASC certification for Macquarie Harbor, because it was failing to meet the council's own minimum oxygen level standards" (Burgess, 2017). The auditors note in the 2017 report that there were concerns raised (predominantly by ENGOs) during the community meeting that the ASC standard was neither adequate nor applied correctly. The auditors report notes Environmental Tasmania's concerns that the auditors interpretation of non-conformities do not align with the environmental impact at the site;

Breaches of ASC standards for DO levels were classified as "minor" in the first ASC surveillance report. At this time evidence from Government data, the Dissolved Oxygen Working Group and IMAS, indicated that DO levels had dropped to worrying levels harbor wide. 
The evidence on DO indicated a systemic failure in the ecology of the harbor such that it could not support farming to ASC standards.

Environment Tasmania argues that "non-compliances" for the companies breaches in DO standards should have been, and should certainly now be, considered major non-conformities.

However, the report finds that the ASC standard was correctly applied in the case of Tassal's Macquarie Harbor leases. Any nonconformities were correctly classified and closed out according the ASC methodology during surveillance audits (see SCS Global Services, 2017). However, the report acknowledges that the ASC standard is globally applicable and local conditions might require a different approach. The auditors state that the standard may require changes, based on further scientific monitoring and potentially a change of monitoring methods, to address local environmental impacts (SCS Global Services, 2017). This is seen in the auditors' response to a general concern raised at the stakeholder meeting that "Tassal has gotten too big too quickly. It has only taken 3 years for the Franklin lease to completely kill the seabed. It makes a mockery of ASC accreditation. How do we know that the same thing won't happen to the Middle harbor and Gordon leases?"(pp: 86):

The recent IMAS report has raised concerns that the compliance monitoring is not adequate to support management and further research has been proposed and additional recommendations were made. Assessments against the ASC standards rely heavily on published information and monitoring surveys rather than its own additional surveys. Therefore, it cannot be judged in isolation. The monitoring system that has been applied in Macquarie Harbor for many years is now under question and will be strengthened. These proposed research and additional monitoring requirement will be included in any further assessment.

The ASC standards have been developed to be globally applicable with international multi-stakeholder engagement over may years. Local conditions may vary greatly from one site to another and, in some cases, a different approach might be necessary to deliver more accurate assessments. Identifying these and feeding them into the standard review process is important for the development of the standard. The audit team has committed to do that and will provide all standard specific issues to the ASC for their consideration.

As it stands the audit team and past reports prepared by SCS and members of the team have been reviewed by the official ASC accreditation body, ASI. The review confirmed our proper understanding and application of the standard. (SCS Global Services, 2017: 86).

This exemplifies the complexities of addressing and communicating the interaction between local and global governance mechanisms and differences in what is considered acceptable level of environmental impact.

\section{Theory: Understanding the Interaction Between Local and Global Discourse}

Transnational communications, governance, knowledge, investment and trade (among others) are pronounced influences in natural resource management. However, as Hutchins and Lester (2015) state, investigating these complex aspects of media, public and policy in local environmental governance in an increasingly transnational world is challenging;

To study conflict in this way and at this scale is no small task, encompassing intricate networks of environmental concern, strategic webs of media and political influence, public policy debates, and $b i$ - and multi-lateral trade negotiations and deals. Nonetheless, it is imperative that this research challenge is met, as this is the arena in which global environmental futures are set to be determined.

The scholarship on global communication, policy and trade emphasizes the role of the local in the global and the importance of maintaining a sense of equality between the two scales when first examining a case. Terms such as "glocalisation" encompassing how economic, political and social dynamics occurring at the global scale influence processes on the local scale and vice versa (Ramutsindela, 2004) and indicate a keen sense of the local in the global. Local threats and global risks are amalgamated to play a role in the decision-making of each (Lester, 2016). Similarly, Ertör and Ortega-Cerdà (2015) state that high-level regional and national policies should never discount local community attitudes and interests because the local level is the level of implementation. If local preferences and values are disregarded, coupled with the growth of a sector (in this case the expansion of fin-fish aquaculture), it becomes a recipe for disaster according to Ertör and Ortega-Cerdá and lessons from these conflicts should underpin the future management of this food production sector. When national and international networks or coalitions are formed, local and global conflict discourses are intertwined and subsequent arguments are the product of a glocal process (Swyngedouw, 1997).

\section{MATERIALS AND METHODS}

\section{Data Collection}

In order to explore information flows concerning the Tasmanian salmon industry and its context in the global operating environment for seafood, environmental sustainability and target markets, two phases of data collection were undertaken; textual analysis of news media articles and semi-structured indepth interviews. News articles were collected from the five most prominent news sources in Australia. Three of these were Tasmanian based newspapers the Hobart Mercury (111), Launceston Examiner (38) and the Burnie Advocate (58), and two were national news sources, the Australian (7) and $A B C$ News (63). News articles were collected using the Factiva news database using the search terms: "salmon farm" OR "fish farm" OR "salmon aquaculture" OR Tassal OR "Huon Aquaculture" OR Petuna. News articles that did not address salmon farming in Tasmania were excluded. For example, many articles published financial updates and share prices and other aquaculture pursuits in Australia. News articles were collected for the 6 months following the Senate Inquiry (15 July 2015 to 15 January 2016) and Four Corners Program "Big Fish" (1 May 2016 to 1 November 2017). Particular attention was paid to international references being made and the context in which they were made. 
To provide greater detail and the opportunity for validation of strategies, mechanisms and claims based on transnational flows, interviews were conducted with 29 individuals. Interview participants were considered to be key informants and were selected based on their ability to represent local through to global aspects of seafood sustainability and trade in the Australia-Asia region (Table 1). Of these interviewees, 16 had experience in the Tasmanian salmon aquaculture and/or Australia trade relations with Asia, 8 operating in a global capacity regarding salmon specifically, seafood more generally and/or global markets, and 5 were experts in Asian business and media. Interviewees were not considered to represent the entire Australia-Asia conditions for which environmental sustainability and seafood trade would operate in. However, the broad cross section of influential and knowledgeable positions of interviewees did provide opportunity for in-depth analysis of concepts and a source of triangulation or verification of results from the textual analysis.

The interviews covered topics of local transnational flows of information regarding seafood sustainability. Participants were asked how they obtained and shared information, identifying interactions and relationships between key stakeholder groups both locally and transnationally. In doing so, specific details were gathered regarding the interviewees' communications practices and strategies. An overview was obtained regarding how the interviewees portrayed their operating environment and their understanding of environmental campaigning, media, and environmental governance. In particular, the interviews explored the processes of claims-making and decision-making processes of ENGOs, seafood companies, government regulators, media, environmental campaigning and the interactions this elicits

TABLE 1 | Areas of expertise that interviewees represented.

\begin{tabular}{|c|c|c|}
\hline $\begin{array}{l}\text { Tasmania-based } \\
\text { interviewees (16) }\end{array}$ & $\begin{array}{l}\text { Asia-based } \\
\text { interviewees (5) }\end{array}$ & $\begin{array}{l}\text { Transnationally } \\
\text { operating interviewees } \\
\text { (8) }\end{array}$ \\
\hline $\begin{array}{l}\text { Communications and } \\
\text { environmental managers } \\
\text { of salmon companies (5) }\end{array}$ & Large Asian retailers (1) & $\begin{array}{l}\text { International } \\
\text { environmental } \\
\text { certification } \\
\text { organizations (2) }\end{array}$ \\
\hline $\begin{array}{l}\text { Journalists reporting on } \\
\text { Tasmanian salmon } \\
\text { aquaculture industry (2) }\end{array}$ & $\begin{array}{l}\text { Journalists reporting on } \\
\text { Asian seafood } \\
\text { dynamics (1) }\end{array}$ & $\begin{array}{l}\text { International companies } \\
\text { in the salmon industry (2) }\end{array}$ \\
\hline $\begin{array}{l}\text { Scientists researching the } \\
\text { environmental aspects of } \\
\text { the salmon industry (2) }\end{array}$ & Industry NGOs (1) & $\begin{array}{l}\text { International journalists } \\
\text { reporting on issues of } \\
\text { seafood in international } \\
\text { media (1) }\end{array}$ \\
\hline Environmental NGOs (3) & Environmental NGOs (1) & $\begin{array}{l}\text { Scientists and science } \\
\text { communicators working } \\
\text { in global seafood } \\
\text { business stewardship (3) }\end{array}$ \\
\hline $\begin{array}{l}\text { Government } \\
\text { regulators (2) }\end{array}$ & $\begin{array}{l}\text { Consultants with } \\
\text { expertise in Chinese } \\
\text { primary industry } \\
\text { business (1) }\end{array}$ & \\
\hline $\begin{array}{l}\text { Government department } \\
\text { for Australia-Asia trade } \\
\text { relations (2) }\end{array}$ & & \\
\hline
\end{tabular}

between these actor groups. The extent to which these either draw upon or contribute to transnational messaging regarding environmental impacts of seafood production was considered. The implications of these networks and conflict discourses for environmental governance at the local and regional level was then explored. Interviews were conducted by the first author from mid 2017 to early 2018, with one conducted by the second author in 2016. The interviews were digitally recorded and professionally transcribed.

\section{Data Analysis}

Critical discourse analysis of qualitative data (interviews and news articles) was conducted by applying an inductive qualitative coding technique using Nvivo 11 software (QSR International). This software allows for descriptive coding to identify and organize ideas, themes, and concepts. Prevalent concepts were organized into hierarchal coding. Discourse has been defined as a "shared way of apprehending the world...constructing meanings and relationship and helping define common sense and legitimate knowledge" (Dryzek, 2013). This critical discourse analysis identified how different actors characterized the transnational elements of salmon aquaculture and seafood globally, indicators that information was flowing transnationally and the mechanisms by which this was occurring, and the outcomes these transnational dimensions had on environmental governance. The analysis focused particularly on the environmental sustainability of the industry.

Linking the two methods of qualitative coding and discourse analysis follows Fleming et al. (2018), which coded key concepts and language use at the sentence level. The analysis identified key themes present in the text (interviews and media content) and organized into codes. These codes were constantly compared, reviewed and redefined as new concepts were identified or merged during analysis.

\section{RESULTS}

The analysis of interviews (Table 2) and news text (Table 3) revealed how different actors determined, and used information to support this determination, whether the industry was or was not meeting international environmental standards for farming salmon. Not only was there a disconnect between international standards and how they are expected to be applied locally, but also how different markets interpret environmental sustainability and what that might mean for local operations. Third-party certification was used by industry as a benchmark for environmentally sustainable practices and as a means of managing the risk of environmental campaigning. However, discrepancies in what is considered acceptable environmental impact between local ENGOs and certification schemes were observed in the research.

Asia, particularly China, is a growing market for Tasmanian farmed salmon. Australian branding and certification indicate to the Chinese consumer that the food is safe, rather than environmentally sustainable. This indicates a gap between local debates at the site of production in Tasmania and the values of 
TABLE 2 | Themes from interviews.

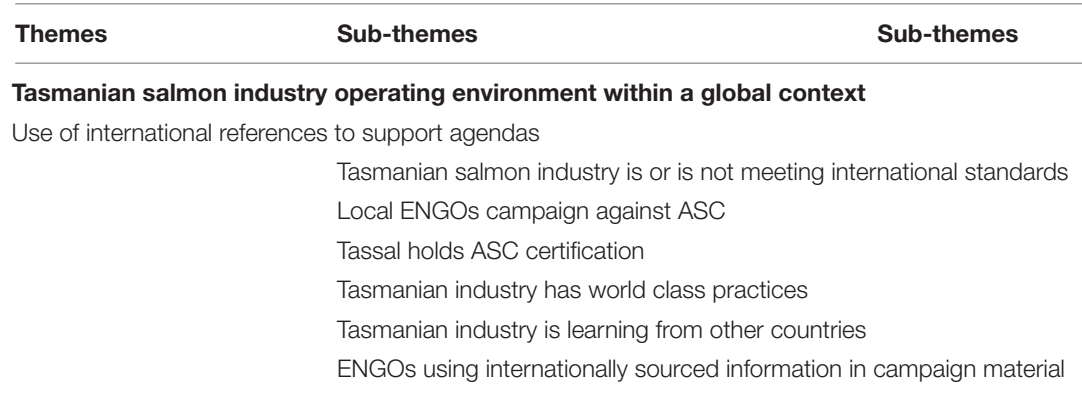

Asia key export market

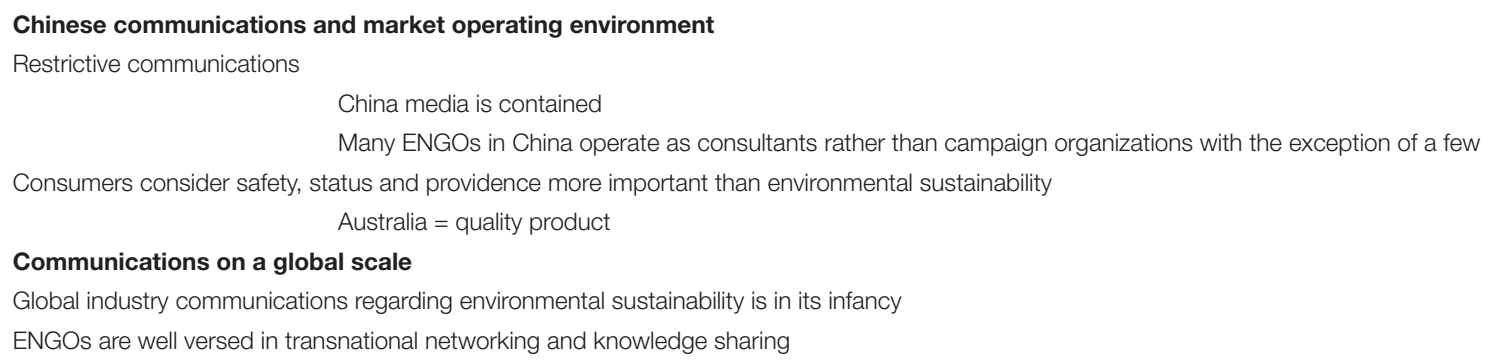

ENGOs seen as a pressure for change

Media as a pressure for change

Importance of transparency

Chinese ENGOs campaigning for Chinese retailers to stop selling Australian product (which has friends of the sea certification)

Certification used by industry to manage risk of environmental campaigning

Transparency between industry and ENGOS

Communication gap between the industry and ENGOs that campaign against industry Observing a shift toward collaboration and understanding between some ENGOs and industry actors

Transparency between industry and the public is increasing

Media facilitates conflict and inhibits open conversation

Varying interpretations of environmental sustainability between countries and how to best achieve it

Certification uses a clear benchmark for industry to define environmental sustainability

the industries international markets. The operating environment for media and ENGOs in China is also considered more restricted than that of Australia. Nonetheless, Chinese ENGOs were observed to be campaigning against selling of Australian product. It was also understood that ENGOs are proficient at facilitating transnational networks and discourse while industry is still gaining momentum at the global level. Industry considered some ENGOs to be a source of support at the global level of discourse regarding environmental sustainability.

\section{Transnational Relationships Between and Among ENGOs and Supply Chain Actors}

The results of the interviews indicated a shift in the relationship between ENGOs and international seafood supply chain actors. Interviewees operating in a transnational capacity in industry, ENGOs, media, retail and certification reported that the degree of collaboration currently observed in relationships between some ENGOs and seafood businesses is vastly different to the mostly hostile relationships between business or industry and NGOs historically. As one interviewee noted, now "we act together, we discuss problems, the NGOs start to understand what is our problem and we start to listen to their problems" (Asiabased interviewee 25). Similarly, transnational Interviewee 17 highlighted that;

Campaigns against salmon farming have shifted from making kind of global unbacked claims to being very well documented claims.

However, it was also acknowledged in the interviews that historically, environmental claims regarding unacceptable environmental impact of harvesting or producing seafood, highlighted in transnational campaigns by global ENGOs, were not always being challenged by the seafood industry with the same efficacy at the global level as ENGO campaigns:

The way (the industry) was segmented nationally, internationally or transnationally, was very peculiar in that there was not always a voice that could address the concerns that were being made on a global scale (Transnational interviewee 17).

Further highlighting the global scale of environmental discourse, industry representatives noted that ENGOs have been putting pressure on them to be responsible for their entire value chain, emphasizing the necessity for global environmental 
TABLE 3 | Themes from news articles.

Themes Sub-themes
Asia key export market
Industry is, or is not, meeting international standards
Using international sources of information to support agendas
Tasmanian salmon industry is world class
Certification

Provides clear standards for industry to achieve

Provides a way for industry to show their practices are environmentally sustainable, safe and ethical

standards and transnational networking mechanisms that facilitate such expansive yet robust process. However, transnational interviewee 19 addressed the presence of alternate opinions between and among stakeholder groups regarding how to best improve or meet environmentally sustainable practices through the value chain. Namely whether it is most effective to be an active participant in a supply chain that could have practices that are considered unsustainable to help improve it or simply to not use those products.

The interviews indicated that managing the commercial risk of environmental campaigning has been one important driver over the past two decades for the global seafood industry to accept and embrace the concept of environmental sustainability. A representative of a prominent Asian retailer identified in interview that the company determined procurement risk areas by using ENGOs, media content and customer surveys as the major sources of information. The interviewee particularly noted that the retailer did not address scientific information in this decision-making process. If during this monitoring process conflict was identified to be present regarding a product they stock, the retailer would send someone from headquarters to local suppliers in an attempt to solve the problem (Asia-based interviewee 25). This interviewee also noted that in response to ENGOs asking retailers to initiate environmental discourse through the supply chain, seminar-type events were set up to instigate information sharing with key stakeholders, such as government, companies and ENGOs in the supplying country. When asked why these retailers work closely with ENGOs the interviewees noted three key reasons; (1) to understand the ideas and thinking of the ENGOs in order to manage the risk of environmental campaigning, (2) to utilize the ENGOs expertise and international networks and, (3) ENGOs provide technical expertise on matters that span international governance boundaries.

A comparable example provided by interviewees was that of Southern Bluefin Tuna, which was produced in Australia and sold in the Asian market with third party environmental certification. In 2017, a major e-commerce platform in Asia, JD.com, posted a photo on social media of a Southern Bluefin Tuna promoting the Australian supplier. In response, a group of Chinese ENGOs campaigned in the Chinese media for JD.com to stop selling the fish based on its International Union for Conversation of Nature (IUCN) critically endangered status. Even though this fish holds the "Friends of the Sea" certification, JD.com ceased selling the tuna within 3 days of the campaign. WWF was also criticized for their partnership with JD.com. Similar to the Tasmanian salmon debate, dialogue between the ENGO and industry was reported to have been limited at best, with all communications occurring via media platforms (Asia-based interviewee 27). While Friends of the Sea serves as a different certification process to ASC, they both advocate for environmentally sustainable seafood and portray this sentiment to consumers. This example reinforces the finding that communication between local and international actors was absent and certification did not, in this instance, provide protection against criticism regarding seafood production practices. This example encompassed a similar set of actors to the salmon case study, but directly operating across the Australia-Asia region (Asian-based and international ENGOs, Australian seafood producers and exporters, global environmental certification schemes, and Chinese media). These actors also appear to disagree about was the acceptable environmental impact of seafood production activities, providing a precedent for conflict between ENGOs and certification schemes to occur in the trade of seafood from Australia into Asia markets.

\section{The Extent to Which Global Discourses Are Used in Local Claims-Making}

Local industry and government actors have used global references in the Tasmanian newspapers by promoting thirdparty certification of the industry and the implementation of what they claimed to be "world class" environmental practices and standards (Rockcliff, 2017). As a rebuttal, local ENGOs promoted international scientific literature and details of international finfish farming practices to assess nuances of the meaning of "world class" standards. For example, it was claimed in the Hobart Mercury:

\begin{abstract}
If you look around the world, it is clear that the future for aquaculture is either land based or properly offshore... Other salmon farming countries like Norway and Canada have arrived at the same conclusion (Wood, 2017).
\end{abstract}

Additionally, the ramifications that local industry practices can have on distant environments and societies was acknowledged in the interviews. For example, if a local company shuts down, retailers must then source the product from elsewhere in the world that may have lower standards or regulatory rigor. Those in support of the industry explained:

If our salmon industry goes by the wayside, the gap will be filled, and the jobs will be taken, by producers in Asia or South America (Walton, 2017).

These potentially undesirable repercussion of extremist approaches on industry and the environment has meant that "we need to be really really careful that we do things very very well here" (Tasmania-based interviewee 8).

Using international materials to underpin local claims is instilling the notion of a "transnational community of concern" (Lester, 2014), giving grass-roots groups a form of legitimacy. Here, local actors use global discourse to strengthen local 
claims. However, the results also indicate there was little connection between local and international perceptions of the Tasmanian salmon industry. For instance, it was perceived among portions of the Tasmanian public that industry and government processes lacked transparency, particularly those associated with Tassal (Whitson, 2017). However, a Tasmanian newspaper highlighted that internationally Tassal had been applauded for its transparency:

TASMANIAN salmon producer Tassal Limited has achieved another sustainability honor, this time on the world stage. ASXlisted Tassal was named as the world's top seafood company for sustainability reporting and transparency in a report rating the top 100 seafood companies on various measures (Ford, 2015).

Tasmanian-based interviewee 9 also highlighted that while Tassal focused on undertaking initiatives of environmental sustainability and transparency that were recognized internationally, namely ASC certification, the company had overlooked the need to engage and promote these initiatives locally early on in their expansion.

The disconnect between local environmental campaigning and global certification schemes regarding the perception of the processes and implementation of certification has created confusion for industry concerning what is deemed "good enough...what is sustainable, what does sustainability mean?" (Tasmania-based interviewee 8) and what mechanisms to determine and practice environmental sustainability are considered legitimate to both the consumer, ENGOs and thirdparty certifiers. This highlights disagreement and conflict over interpretation of fact (e.g., whether something is transparent), which can be based on different sources of information, values and priorities driving how that information is perceived.

\section{Certification as a Mechanism of Transnational Flow of Information Regarding Environmental Sustainability of Seafood Production}

Seafood buyers acknowledged certification schemes were useful tools to help identify seafood that is more likely to align with their purchasing policies (Asia-based interviewee 25). However, a range of interviewees highlighted that global third-party certification schemes for environmental sustainability were still undergoing improvements and identified that the relationship between environmental certification and environmental sustainability was strained. One transnational interviewee (18) depicted some of the challenges by explaining "not everything that is certified is by definition sustainable, but definitely not everything that is sustainable is certified." This provides considerable challenges for those either wishing to produce or purchase environmentally sustainable seafood and to show that they are doing so.

Defining environmentally sustainable practices and how best to assess them can vary between and within stakeholder groups. For example, consumers in different countries "have different concepts of what sustainability means and different levels of urgency to address those issues" (Transnational interviewee 19).
At the site of salmon production in Tasmania local actors defined environmental sustainability by its impact on the immediate environment (e.g., benthic and water quality, fauna and flora and asthetics). However, for the Chinese consumer, any indication of environmental certification is used as a proxy for provenance. Provence indirectly implies food safety or freshness. Here, this is not a different interpretation of sustainability but rather indicates that these customers value the supply chain traceability associated with the certification label over sustainability. Furthermore, ENGOs and those involved in thirdparty certification had only just started to engage in matters of environmental sustainability with the Chinese seafood supply chain (Transnational interviewees 17 and 19). As China shifts to a net importer, rather than certifying Chinese products, certification bodies and ENGO efforts were said to be focusing on raising awareness of sustainable purchasing practices in China (Transnational interviewee 16). Additionally, Chinese media and politics was said to be considerably complex to navigate (Asiabased interviewee 29). For example, in order to gain access to moderated countries such as China the larger transnational ENGOs (e.g., WWF and Greenpeace) are said to act as more of a consultant to government, rather than activist organizations (Asia-based interviewee 29). A speaker at the 2018 Asian Seafood Expo explained that the environmental sustainability of a seafood product only becomes an area of concern or discourse theme in markets more established than those in China (field notes, Asian Seafood Expo 2018).

\section{DISCUSSION}

\section{Closing and Widening the Gap Between Local and Global Perceptions of Environmental "Best Practice"}

Global perceptions of "world's best practice" were employed in local discourse to support opposing agendas. Actors used references to global standards to either endorse or discredit local actions. This strategy either closed the gap between the local and global or distanced the two. Both strategies were employed to serve the same purpose of measuring local environmental risk of salmon aquaculture. In an attempt to close the gap, the Tasmanian government and industry actors initiated claims of "world's best practice" and promoted third-party certification as assurances that local-level environmental risks are sustainably managed. Meanwhile, opposition groups promoted scientific and news material from other countries that farm salmon to support assertions of environmental risk in Tasmania. Here ENGOs are leveraging the notion of a "transnational community of concern" (Lester, 2014) to legitimize their claims. This strategy aligns with Olsen and Osmundsen's (2017) media analysis of salmon aquaculture in Norway, which finds that connection made with global discourse can have a greater influence on the perceptions of the environmental risks of aquaculture compared to local experiences. Alternatively, local ENGOs also created a gap between local and global standards to portray a perceived mismanagement at the local level and attacked 
the ASC for being corrupt. Here the ASC standard might well be considered adequate as certification but inadequate in its application. What is also not considered in this use of international references in the Tasmanian case is that different growing regions experience different social and environmental challenges (Vince and Haward, 2017).

The disconnect between local and international interpretations of "best practice" was initially only evident through piecing together discourse in news media articles. However, the gap between local and international interpretations and applications of environmental "best practice" was later made obvious when local ENGO, Environment Tasmania, campaigned against the transnational ENGO WWF and the ASC and their partnership and certification of Tassal (Environment Tasmania, 2017). Given the national and international credibility the WWF and ASC symbol holds and the market capacity this has to promote the idea of sustainability and associated practices, it becomes a question of what is considered legitimate application of environmentally sustainable standards to different actors in different world regions. Environment Tasmania also collaborated with the transnational ENGO Marine Stewardship Council to develop a sustainable salmon consumer guide. Seafood guides have been a long-standing tool used by ENGOs to promote their perceptions of environmentally sustainable practices to consumers. However, these have also highlighted the lack of consensus among ENGOs and between ENGOs and industry when defining sustainable seafood (Roheim, 2009). Additionally, third-party certification schemes have been criticized for favoring large-scale fisheries in the developed world. This highlights that while balancing local and global communications is challenging, it is important to ensure one is not considered without the other, especially when supply chains of both product and information have local and global dimensions (Olson et al., 2014). This case shows that variation in environmental "best practice" perceptions underpin stakeholder conflicts at both local and international levels.

\section{Third-Party Certification as a Tool to Communicate "Best Practice"}

Third party certification of a product does not guarantee local acceptance of a practice, nor should it form the only mechanism by which a company demonstrates or defines "best practice." This aligns with Ertör and Ortega-Cerdà (2015), who argued that local interests and concerns should never be discounted in global communications and governance. While Tassal focused on achieving international standards in environmental sustainability and reporting (ASC certification), the company is said to have lacked local stakeholder engagement at the site of production. Local opposition groups voiced concerns regarding the perceived lack of transparency of the Tasmanian salmon industry, particularly Tassal. Meanwhile, the salmon company received international praise for transparency regarding its sustainability reporting. Interviewees reported that the company was potentially too complacent in its expectation that their commitment to achieving international environmental and reporting standards would filter through and be accepted, to local communities. This is perceived to have contributed to the opposition from a portion of concerned communities in Tasmania and a disconnect between these groups and international standard-setting stakeholders and actors.

This work brings to the forefront the importance, and at times difficulty, of acknowledging and attempting to reconcile between local and international standards regarding acceptable environmental risk. Aligning local expectations and interpretations of environmental impact (identified by environmental campaigning) and global standards (e.g., ACS certification) is complex and the processes poorly communicated. Local ENGOs claim that global standards do not fit the local reality. This work also highlights that claims of "world's best practice" and global governance mechanisms regarding environmental sustainability are not as easily accepted where transnational flows of information regarding environmental practices and environmental concerns are relatively effortless, frequent and available. This then highlights the role of ENGOs in the selection and distribution of that information, given their transnational networks. Equally, this analysis highlights the capacity for these transnational flows to transfer information to sites of local production and influence discourse on the basis of transnational claims that do not reflect or are irrelevant to the sustainability issues at hand.

\section{Environmental Campaigning and Media Forces in Defining Acceptable Practices in the Australia-Asia Region}

The degree of contestation of the environmental sustainability status and credentials of seafood, and international variations of what is considered acceptable environmental impact, may explain why the strategies of ENGOs operating in the transnational space are shifting. Rather than ENGOs solely being institutions for protest and campaigning, actors throughout the supply chain perceived some ENGOs as sources of expertise and insight. They provide expertise in not only how to produce and purchase environmentally sustainable products but also in how to influence the international social networks involved in sustainability. ENGOs are also seen to be utilizing processes whereby they create environmental discourse through the supply chain by using the resources of large retail companies to send messages transnationally, easily targeting key decisionmakers within the supply chain. Nonetheless, in a key export market for Australian seafood such as China, media coverage can be a powerful driver when it affects buyers' choices. This study suggests that rather than local conflicts from the site of production transferring to international markets, it is more likely for Chinese media and ENGOs to create pressure on imported product. While some ENGOs and journalists can create pressure for change these actors express the difficulty of operating in China. The interviews identified the apparent lack of ENGO presence in Asian countries, particularly in the capacity for which they are known in most western countries.

While China is the major export market for Australian farmed salmon it is also a country that interviewees who work transnationally on seafood sustainability know little about. 
Only in recent years have these actors begun to engage in issues of environmental sustainability within China. This aligns with Fabinyi (2016) who states Asian consumers are said to have less exposure and/or desire to address environmental concerns in their purchasing practices. Therefore if unsustainable environmental harm is (not just perceived to be) occurring at the site of production, exports to Asian markets continue to grow as predicted (Linehan et al., 2013) and Asian consumer preferences do not send signals through markets for environmentally sustainable product, then other non-market mechanisms, such as protest campaigns and regulatory rigor, could have a greater role to play at the site of production or extraction to ensure environmental sustainable standards are met. The interviewees also discussed the implications for global net environmental impact of seafood production, because of the ease of product substitution. This highlights the responsibility of ENGOs running environmental campaigns to consider possible unintended consequences - for example, exploitation of less managed fisheries close to markets to meet food security needs if imported product is halted.

\section{CONCLUSION}

This paper has explored the transnational flow of information, resources, perceptions and governance of environmentally sustainable seafood. Tasmanian salmon aquaculture provided a local context from which the research could expand. By traversing local and global scales, this research contributed to understanding the mechanisms for which information regarding the environmental risk of seafood production flows transnationally. In doing so it also identified some of the risks of not addressing both local and global factors in communication and governance strategies.

Contributing to the difficulty of communicating environmental sustainability is the apparent lack of shared understanding concerning what constitutes environmentally sustainable practices and how to govern this in an increasingly transnational operating environment. Local and international perceptions and expectations regarding the sustainability requirements of salmon companies did not align in the case of the Tasmanian salmon industry. The interpretation and meaning of environmentally sustainable seafood production shifts as it moves from the site of production through the supply chain to export markets. These differences in the interpretations of environmental sustainability underpin stakeholder conflicts at both local and international levels. The challenge for all actors is to ensure communications and management practices and

\section{REFERENCES}

ABC News, (2016). “G20: malcolm turnbull warns against isolationism," in Meets With Chinese President (New York, NY: ABC News).

Beck, U. (1996). World risk society as cosmopolitan society? Ecological questions in a framework of manufactured uncertainties. Theory Cult. Soc. 13, 1-32. doi: 10.1177/0263276496013004001

Beck, U. (2011). Cosmopolitanism as imagined communities of global risk. Am. Behav. Sci. 55, 1346-1361. doi: 10.1177/00027642114 09739 strategies address concerns at the local level while operating within global governance, market and resource pressures.

\section{DATA AVAILABILITY STATEMENT}

The datasets generated for this study will not be made publicly available. Data includes interviews and remain confidential.

\section{ETHICS STATEMENT}

The studies involving human participants were reviewed and approved by the Tasmanian Health and Medical Human Research Ethics Committee, University of Tasmania (H14669). The participants provided their written informed consent to participate in this study.

\section{AUTHOR CONTRIBUTIONS}

All authors contributed to the conception and design of the study, development of the argument, manuscript revision, and read and approved the submitted version. CC was the primary author and wrote the first draft of the manuscript, coordinated all revisions, and collected and analyzed the data. This work forms a component of her Ph.D thesis. LL, AF, and EO are her supervisors.

\section{FUNDING}

The authors of this paper would like to acknowledge the support of The Centre for Marine Socioecology and the Australian Government Research Training Program Scholarship. This research was also supported in part by the Australian Government through the Australian Research Council's Discovery Projects funding scheme (DP150103454) "Transnational Environmental Campaigns in the AustraliaAsian Region." This research did not receive any specific grant from funding agencies in the public, commercial or not-for-profit sectors.

\section{ACKNOWLEDGMENTS}

The authors would like to thank all participants in the research and the reviewers for their contributions. 
Carvalho, A. (2005). Representing the politics of the greenhouse effect: discursive strategies in the british media. Crit. Discourse Stud. 2, 1-9.

Commonwealth of Australia (2012). Australia in the Asian Century White Paper. Available online at: http://www.defence.gov.au/whitepaper/2013/docs/ australia_in_the_asian_century_white_paper.pdf (accessed January 25, 2017).

Crona, B. I., Basurto, X., Squires, D., Gelcich, S., Daw, T. M., Khan, A., et al. (2016). Towards a typology of interactions between small-scale fisheries and global seafood trade. Mar. Policy 65, 1-10. doi: 10.1016/j.marpol.2015.11.016

Cullen-Knox, C., Fleming, A., Lester, L., and Ogier, E. (2019). Publicised scrutiny and mediatised environmental conflict: the case of tasmanian salmon aquaculture. Mar. Policy 100, 307-315. doi: 10.1016/j.marpol.2018.11.040

Cullen-Knox, C., Haward, M., Jabour, J., Ogier, E., and Tracey, S. R. (2017). The social licence to operate and its role in marine governance: insights from Australia. Marine Policy 79, 70-77. doi: 10.1016/j.marpol.2017.02.013

Dryzek, J. S. (2013). The Politics of the Earth: Environmental Discourses. Oxford: Oxford University Press.

Environment Tasmania (2016). Misleading Consumers: Tassal, Asc And Wwf. Available online at: https://Www.Et.Org.Au/Misleading_Consumers (accessed September 18, 2019).

Environment Tasmania (2017). David Versus Goliath: Tasmanian Environment Groups Demand An End To Salmon Certifier's Conflict Of Interest. Available online at: https://Www.Et.Org.Au/Tas_Environment_Groups_Demand_An_ End_To_Salmon_Certifier_Conflict_Of_Interest (accessed March 8, 2019).

Environment Tasmania (2019). A Fresh Approach: Tasmanian Salmon Consumers Guide. Available online at: https://d3n8a8pro7vhmx.cloudfront.net/marine/ pages/2155/attachments/original/1574374357/ET_consumers_guideFINAL_ CORRECT_LOGO_\%281\%29.pdf?1574374357 (accessed October 22, 2018).

Ertör, I., and Ortega-Cerdà, M. (2015). political lessons from early warnings: marine finfish aquaculture conflicts in Europe. Mar. Policy 51, 202-210. doi: 10.1016/j.marpol.2014.07.018

Fabinyi, M. (2007). The Chinese Seafood Market: Opportunities and Challenges for Australian Exporters. Ultimo, NSW: Australia-China Relations Institute.

Fabinyi, M. (2016). Sustainable seafood consumption in China. Mar. Policy 74, 85-87. doi: 10.1016/j.marpol.2016.09.020

Fabinyi, M., Barclay, K., and Eriksson, H. (2017). Chinese trader perceptions on sourcing and consumption of endangered seafood. Front. Mar. Sci. 4:181.

Fabinyi, M., Pido, M., Harani, B., Caceres, J., Uyami-Bitara, A., De Las Alas, A., et al. (2012). Luxury seafood consumption in china and the intensification of coastal livelihoods in southeast asia: the live reef fish for food trade in Balabac. Philippines. Asia Pac. Viewp. 53, 118-132. doi: 10.1111/j.1467-8373. 2012.01483.x

FAO, (2016). The State of World Fisheries and Aquaculture. Rome: FAO.

Fleming, A., Mason, C., and Paxton, G. (2018). Discourses of technology, ageing and participation. Palgrave Commun. 4:54.

Foley, P., and Havice, E. (2016). The rise of territorial eco-certifications: new politics of transnational sustainability governance in the fishery sector. Geoforum 69, 24-33. doi: 10.1016/j.geoforum.2015.11.015

Ford, S. (2015). Tasmanian salmon producer tassal limited has achieved another sustainability honour. Burnie Advocate

Fraser, N. (2007). Transnationalizing the public sphere: on the legitimacy and efficacy of public opinion in a post-westphalian world. Theory Cult. Soc. 24, 7-30. doi: 10.1177/0263276407080090

FRDC, (2018). Seafood Import And Export By Species. Available at: http://Www.Frdc.Com.Au/Services/Seafood-Trade-And-Market-Access/ Seafood-Import-And-Export-By-Species (accessed December 12, 2018).

Hatanaka, M., Bain, C., and Busch, L. (2005). Third-party certification in the global agrifood system. Food Policy 30, 354-369. doi: 10.1016/j.foodpol.2005.05.006

Hutchins, B., and Lester, L. (2015). theorizing the enactment of mediatized environmental conflict. Int. Commun. Gaz. 77, 337-358. doi: 10.1177/ 1748048514568765

IUCN, (1980). World Conservation Strategy: Living Resource Conservation For Sustainable Development. Switzerland: IUCN.

Kate, B., and Alice, M. (2018). The sustainable seafood movement is a governance concert, with the audience playing a key role. Sustainability 10, 1-20. doi: 10.4324/9781315161228-1

Kolodny, L. (2017). Gfresh Raises \$20 Million to Transform the Way Seafood is Bought and Sold. Available at: https://Techcrunch.Com/2016/11/03/Gfresh-
Raises-20-Million-To-Transform-The-Way-Seafood-Is-Bought-And-Sold/ (accessed March 14, 2019).

Lester, L. (2014). Transnational publics and environmental conflict in the asian century. Media Int. Aust. 150, 167-178. doi: 10.1177/1329878x1415000128

Lester, L. (2016). Containing spectacle in the transnational public sphere. Environ. Commun. 10, 791-802. doi: 10.1080/17524032.2015.1127849

Linehan, V., Thorpe, S., Gunning-Trant, C., Heyhoe, E., Harle, K., Hormis, M., et al. (2013). "Global food production and prices to 2050: scenario analysis under policy assumptions," in Paper Presented at the 43rd ABARES Outlook Conference (Canberra: ACT).

MacDonald, L. (2018). Tasmania Independence at Risk From Chinese Investment Says Australian Academic. Available at: https://Www.Abc.Net.Au/News/ 2018-10-03/Clive-Hamlton-On-China-Relationship-To-Tasmania/10329236 (accessed June 6, 2019).

McEwan, C., and Bek, D. (2009). The political economy of alternative trade: social and environmental certification in the south african wine industry. J. Rural Stud. 25, 255-266. doi: 10.1016/j.jururstud.2009.03.001

Miller, A. (2014). Governance Innovation Networks For Sustainable Tuna. Wageningen: Wageningen University.

O'Conner, C. (2018). Foreign Ownership And Influence. Available at: https://Tasmps.Greens.Org.Au/Content/Foreign-Ownership-And-Influence (accessed June 9, 2019).

Olsen, M. S., and Osmundsen, T. C. (2017). Media framing of aquaculture. Marine Policy 76, 19-27. doi: 10.1016/j.marpol.2016.11.013

Olson, J., Clay, P. M., and Pinto Da Silva, P. (2014). Putting the seafood in sustainable food systems. Marine Policy 43, 104-111. doi: 10.1016/j.marpol. 2013.05.001

Ramutsindela, M. (2004). Glocalisation and nature conservation strategies in 21st- century southern africa. Tijdschrift Voor Economische En Sociale Geografie 95, 61-72. doi: 10.1073/pnas.16131 69114

Rice, J. (2014). Evolution of international commitments for fisheries sustainability. Ices J. Mar. Sci. 71, 157-165. doi: 10.1093/icesjms/fst078

Rockcliff, J. (2017). Science backs the job-creating salmon farm on our east coast. Hobart Mercury

Roheim, C. A. (2009). An evaluation of sustainable seafood guides: implications for environmental groups and the seafood industry. Mar. Resour. Econ. 24, 301-310. doi: 10.1086/mre.24.3.42629657

SCS Global Services, (2017). Aquaculture Stewardship Council Salmon Standard Re - Assessment Report: Tassal Operations Pty Ltd - Western Zone (Mf 214 Middle Harbour And Mf219 Gordon). Emeryville, CA: SCS Global Services.

Seghezzo, L. (2009). The five dimensions of sustainability. Environ. Polit. 18, 539-556. doi: 10.1080/09644010903063669

Steneck, R. S., Hughes, T. P., Cinner, J. E., Adger, W. N., Arnold, S. N., Berkes, F., et al. (2011). Creation of a gilded trap by the high economic value of the maine lobster fishery. Conserv. Biol. 25, 904-912. doi: 10.1111/j.1523-1739. 2011.01717.x

Swyngedouw, E. (1997). "rethinking the roles of non-governmental organisations at the world trade organization," in Spaces of Globalization: Reasserting the Power of the Local, ed. K. Cox (New York: Guilford Press).

Tarrow, S. (2005). The New Transnational Activism. New York: Cambridge University Press.

Tasmanian Government, (2013). Tasmania's Place in the Asian Century White Paper. Hobart: Tasmanian Government.

Tasmanian Government, (2017). Available at: https://Dpipwe.Tas.Gov.Au/SeaFishing-Aquaculture/Marine-Farming-Aquaculture/Changes-To-SalmonIndustry-Regulation/Salmon-Industry-Growth-Plan (accessed August 14, 2018).

Tassal, (2018). Sustainability. Available at: http://Www.Tassal.Com.Au/ Sustainability/ (accessed August 21, 2018).

Thompson, S., Lacy, C., and Shore, S. (2011). A Chinese Lesson For Tassal. Available at: https://Www.Afr.Com/Opinion/A-Chinese-Lesson-For-Tassal20111124-Iz29f (Accessed June 6, 2019).

Vince, J., and Haward, M. (2017). Hybrid governance of aquaculture: opportunities and challenges. J. Environ. Manag. 201, 138-144. doi: 10.1016/j.jenvman.2017. 06.039

Walton, D. (2017). Salmon industry leads the world. Hobart Mercury 
Whitson, R. (2017). Concerns Tassal 'Concealed Evidence Of Major Fish Kill' Amid Call For More Transparency. Available at: https://Www.Abc.Net.Au/ News/2017-05-02/Tassal- Accused-Of-Covering-Up-Fish-Kill-In-MacquarieHarbour/8490994 (accessed June 11, 2019).

Wood, G. (2017). Aquaculture can be good business. Hobart Mercury

Woodruff, R. (2017). Threat to fish farm jobs and green brand. Hobart Mercury

World Bank, (2014). Fish to 2030: Prospects for Fisheries and Aquaculture; Agriculture and Environment Services Discussion Paper 3, World Bank Report Number 83177- GLB. Washington, DC: World Bank Group.
Conflict of Interest: The authors declare that the research was conducted in the absence of any commercial or financial relationships that could be construed as a potential conflict of interest.

Copyright $(02020$ Cullen-knox, Fleming, Lester and Ogier. This is an open-access article distributed under the terms of the Creative Commons Attribution License (CC BY). The use, distribution or reproduction in other forums is permitted, provided the original author(s) and the copyright owner(s) are credited and that the original publication in this journal is cited, in accordance with accepted academic practice. No use, distribution or reproduction is permitted which does not comply with these terms. 